\title{
Perancangan Infografik sebagai Media Pendukung Sosialisasi KPU ke Daerah Terpencil
}

\author{
M. Edo Pratama Putra ${ }^{1)}$ \\ ${ }^{1)}$ Program Studi Penciptaan Seni Desain Komunikasi Visual, Pascasarjana Institut Seni Indonesia Yogyakarta \\ Jl. Suryodiningratan No. 8, Mantrijeron, Kota Yogyakarta, Daerah Istimewa Yogyakarta \\ Email : kataedho1@gmail.com ${ }^{1)}$
}

\begin{abstract}
The General Election was held in 2019 with the KPU as the organizer on April 17, 2019. Among the tasks of the KPU was the dissemination of General Elections to remote areas throughout Indonesia. Remote areas are the main concern of the KPU in an effort to increase election participation in 2019, because remote areas are one of the biggest contributors to the Golput number in the 2014 elections. One of the remote areas with very low participation rates is Tegal Rejo Village, Gedang Sari District, Gunung Kidul Regency. This village is located in a hilly area which is one of the disaster prone areas. Tegal Rejo village has not received socialization from the Gunung Kidul Regency KPU and many villagers are still not informed about the 2019 Presidential Election. From the problems that occur, the author finds a solution to the problem by making an "Infographic Design as a Media Supporting the Socialization of KPU to Remote Areas". As for this design contains information on Election 2019, such as the introduction of candidates in the form of profiles of each prospective president and vice president, procedures for voting, time and place of execution until the conditions become a Permanent Voters List (DPT). And the media created will be given to the KPU to be the material for dissemination to remote areas in Indonesia.
\end{abstract}

Keywords : Infographics, Socialization of KPU, Remote Areas

\begin{abstract}
ABSTRAK
Pada tahun 2019 Komisi Pemilihan Umum mengadakan Pemilihan Umum berupa Pemilihan Presiden dan Wakil Presiden, yang akan dilaksanakan pada 17 April 2019. diantara tugas yang dijalankan KPU adalah berupa sosialisasi Pemilihan Umum ke daerah-daerah terpencil di seluruh Indonesia. Daerah terpencil menjadi perhatian utama KPU dalam upaya peningkatan partisipasi Pemilu pada tahun 2019, karena daerah terpencil menjadi salah satu penyumbang angka Golput terbesar di Pemilu tahun 2014. Salah satu penyebab kurangnya angka partisipasi pemilih adalah diantaranya sedikitnya pengetahuan dan informasi masyarakat tentang Pemilu di daerah-daerah terpencil Indonesia. Salah satu daerah terpencil yang tingkat partisipasinya sangat rendah adalah Desa Tegal Rejo Kecamatan Gedang Sari, Kabupaten Gunung Kidul. Desa ini terletak di daerah perbukitan yang menjadi salah satu daerah rawan bencana. Desa Tegal Rejo belum mendapat sosialisasi dari KPU Kabupaten Gunung Kidul dan masyarakat desa masih banyak yang tidak mendapat informasi mengenai Pemilihan Presiden 2019. Dari permasalahan yang terjadi, penulis menemukan usulan pemecahan masalah yaitu dengan membuat sebuah "Perancangan Infografik sebagai Media Pendukung Sosialisasi KPU ke Daerah Terpencil”. Adapun pada perancangan ini berisikan tentang Informasi Pemilu 2019, seperti pengenalan calon berupa profil setiap calon peresiden dan wakil presiden, tata cara mencoblos, waktu dan tempat pelaksanaan hingga syarat-syarat menjadi Daftar Pemilih Tetap (DPT). Dan media yang dibuat akan diberikan kepada KPU untuk menjadi bahan sosialisasi ke daerah-daerah terpencil di Indonesia.
\end{abstract}

Kata kunci : Infografik, Sosialisasi KPU, Dearah Terpencil 


\section{Pendahuluan}

Undang-undang No.22 Tahun 2007 tentang Penyelenggaraan Pemilihan Umum diatur mengenai penyelenggara Pemilu yang dilaksanakan oleh suatu Komisi Pemilihan Umum (KPU) yang bersifat nasional, tetap dan mandiri. Tugas pokok dan wewenang KPU adalah : Menyelenggarakan Pemilu Anggota DPR, DPD, DPRD Provinsi dan DPRD Kabupaten Kota; Menyelenggarakan Pemilu Presiden dan Wakil Presiden; Menyelenggarakan Pemilu Kepala Daerah dan Wakil Kepala Daerah; Salah satu tugas penting dalam penyelenggaraan Pemilu tersebut adalah melaksanakan penyampaian informasi melalui sosialisasi kepada masyarakat luas.

Menurut peraturan KPU No. 10 tahun 2018 tentang Sosialisasi, Pendidikan Pemilih, dan Partisipasi Masyarakat dalam Penyelenggaraan Pemilihan Umum menjelaskan bahwa KPU adalah lembaga penyelenggaraan Pemilu yang bersifat nasional, tetap dan mandiri. Kemudian peran KPU dalam sosialisasi merupakan proses penyampaian informasi mengenai sistem, tata cara teknis, tahapan, program dan jadwal, hasil pemilu serta hal-hal lain tentang penyelenggaraan Pemilihan Umum.

Pada tahun 2019 Komisi Pemilihan Umum mengadakan Pemilihan Umum berupa Pemilihan Presiden dan Wakil Presiden, yang akan dilaksanakan pada 17 April 2019. Oleh karena itu KPU kembali akan menjalankan berbagai tugas di Pemilu 2019 ini, diantara tugas yang dijalankan KPU adalah berupa sosialisasi Pemilihan Umum ke daerah-daerah terpencil di seluruh Indonesia. Daerah terpencil menjadi perhatian utama KPU dalam upaya peningkatan partisipasi Pemilu pada tahun 2019, karena daerah terpencil menjadi salah satu penyumbang angka Golput terbesar di Pemilu tahun 2014.

Melihat landasan normatif dalam rangka pelaksanaan sosialiasi KPU di Pemilihan Umum 2019, maka dari hasil Pilpres tahun 2014 yang didapat dari Badan Pusat Statistik (BPS) jumlah pemilih dari data yang berhasil dihimpun hanya sebesar 69,58\% (DPT 190,3 juta sedangkan jumlah pemilih yang menggunakan hak pilihnya sebesar 130,7 juta) mengalami penurunan partisipasi pemilih bila dibandingkan dengan Pilpres pada tahun 2009 sebesar 71,17\% (DPT 176,3 juta sedangkan jumlah pemilih yang menggunakan hak pilihnya 127,9 juta).

Salah satu penyebab kurangnya angka partisipasi pemilih adalah diantaranya sedikitnya pengetahuan dan informasi masyarakat tentang Pemilu di daerah-daerah terpencil Indonesia. Salah satu daerah terpencil yang tingkat partisipasinya sangat rendah adalah salah satu Desa di Daerah Istimewa Yogyakarta yaitu Desa Tegal Rejo Kecamatan Gedang Sari, Kabupaten Gunung Kidul. Desa ini terletak di daerah perbukitan yang menjadi salah satu daerah rawan bencana, Desa Tegal Rejo memiliki $11 \mathrm{RW}$ dan $54 \mathrm{RT}$ yang sebagian masyarakat berprofesi sebagai petani, jarak desa Tegal Rejo ke Pemerintah Daerah Kabupaten Gunung Kidul sejauh 45 km sedangkan jarak ke Pemerintahan DIY sejauh 50 km, dan terdapat dua dusun yang belum ada aliran listrik yaitu Dusun Gupit dan Dusun Ketelo. Desa Tegal Rejo belum mendapat sosialisasi dari KPU Kabupaten Gunung Kidul dan masyarakat desa masih banyak yang tidak mendapat informasi mengenai Pemilihan Presiden 2019 (Sumber : KPU Gunung Kidul 2018).

Dari permasalahan yang terjadi, penulis menemukan usulan pemecahan masalah yaitu dengan membuat sebuah "Perancangan Infografik sebagai Media Pendukung Sosialisasi KPU ke Daerah Terpencil". Adapun pada perancangan ini berisikan tentang Informasi Pemilu 2019, seperti pengenalan calon berupa profil setiap calon peresiden dan wakil presiden, tata cara mencoblos, waktu dan tempat pelaksanaan hingga syarat-syarat menjadi Daftar Pemilih Tetap (DPT). Dan media yang dibuat akan diberikan kepada KPU untuk menjadi bahan sosialisasi ke daerah-daerah terpencil di Indonesia.

\section{A. Rumusan Masalah}

Adapun perumusan masalah yang terdapat pada "Perancangan Infografik Sebagai Media Pendukung Sosialisasi KPU ke Daerah Terpencil" adalah bagaimana merancang media infografik yang mampu memberikan informasi Pilpres 2019 yang informatif dan mudah dimengerti masyarakat daerah terpencil dalam upaya meminimalisir angka golput dan meningkatkan partisipasi pemilih.

\section{B. Batasan Masalah}

Batasan masalah dalam perancangan ini adalah dibatasi dari aspek geografis masyarakat terpencil sebagai target sekunder dan masyarakat Desa Tegalrejo Kabupaten Gunung Kidul, Yogyarkarta sebagai target primer. Perancangan dibatasi pada permasalahan teknis berupa proses memilih di TPS, aturan mencoblos surat suara, syarat menjadi DPT, profil Calon Presiden dan Calon Wakil Presiden beserta visi dan misi. Media pendukung yang digunakan berupa Infografik sebagai media utama, poster dan katalog sebagai media pendukung.

\section{Tujuan}

Tujuan dalam Perancangan Infografik Sebagai Media Pendukung Sosialisasi KPU ke Daerah Terpencil adalah untuk memberikan informasi Pemilu yang lengkap, informatif dan mudah dipahami masyarakat daerah terpencil. Tujuan lain adalah untuk meminimlisir angka golput dan meningkatkan partisipasi pemilih serta untuk meningkatkan efektifitas KPU dalam melaksanakan sosialisasi Pemilu ke daerah terpencil.

\section{Manfaat}

Adapun manfaat dalam perancangan ini adalah untuk mencerdaskan masyarakat daerah terpencil dan memberikan informasi yang valid terhadap sistem Pemilu 2019, diharapkan perancangan ini akan menjadikan masyarakat lebih antusias menggunakan hak suaranya dengan baik. Manfaat lain adalah untuk 
dijadikan sebagai bahan sosialisasi KPU ke daerah terpencil pada Pemilu 2019.

\section{E. Metode Perancangan}

Perancangan ini menggunakan metode perancangan Design Thinking dengan beberapa tahap, yakni: Empathise, Define, Ideate, Prototype, dan Test. Metode perancangan ini dipilih karena membuka kesempatan bagi desainer untuk melakukan eksperimen terhadap ide baru yang inovatif dengan tetap pada manusia dan kebutuhannya. Adapun bagan Design Thinking, adalah berpusat sebagai berikut:

Emphatise merupakan tahapan yang berpusat pada manusia. Proses ini menuntut pemahaman empatik desainer mengenai permasalahan yang ada dan apa kebutuhan manusia di dalamnya. Tahap kedua yakni, Define. Informasi-informasi lebih dalam yang berkaitan dengan permasalahan kemudian diteliti, dikumpulkan, dan dianalisis. Data-data yang telah diidentifikasi dan dianalisis pada tahap kedua akan disintesis di tahap berikutnya, yakni, Ideate. Tahap ini merupakan tahap dimana desainer melakukan penjelajahan terhadap ideide yang inovatif untuk memecahkan masalah. Tahap selanjutnya adalah Prototype, berisi alternatif visual sebagai pemecahan masalah dalam media yang dipilih. Tahap terakhir dalam metode ini adalah tahap Test. Pada tahap test ini dilakukan pengujian pada visualisasi di tahap Prototype. Pengujian ini bertujuan untuk menentukan desain akhir yang diluncurkan sebagai pemecahan masalah dan menghadirkan pernyataan akhir mengenai desain yang dipilih untuk menyelesaikan masalah.

\section{Pembahasan}

\section{A. Data Objek}

Partisipasi pemilih menjadi salah satu kebutuhan agar sebuah demokrasi dan sistem politik tidak mengalami hambatan. Penurunan angka partisipasi pemilih pada tahun 2014 harus menjadi perhatian KPU yang harus diutamakan. Pemilu sebagai instrumen utama demokrasi merupakan salah satu instrumen yang menjembatani suara rakyat sebagai pemilik kedaulatan untuk memberikan mandat kepada seseorang sebagai wakil rakyat atau sebagai penguasa yang akan duduk dalam pemerintahan (Wahidin, 2008:47).

Melihat landasan normatif dalam rangka pelaksanaan sosialiasi KPU di Pemilihan Umum 2019, maka dari hasil Pilpres tahun 2014 jumlah pemilih dari data yang berhasil dihimpun hanya sebesar 69,58\% (DPT 190,3 juta sedangkan jumlah pemilih yang menggunakan hak pilihnya sebesar 130,7 juta) mengalami penurunan partisipasi pemilih bila dibandingkan dengan Pilpres pada tahun 2009 sebesar 71,17\% (DPT 176,3 juta sedangkan jumlah pemilih yang menggunakan hal pilihnya 127,9 juta) (Sumber: Badan Pusat Statistik (BPS) 2014).

Fenomena lainnya berkaitan dengan sosialisasi Pemilukada di Kecamatan Gedangsari tahun 2015 antara lain peran KPU dalam melaksanakan sosialisasi pemilihan umum di daerah sebagaimana yang dilaksanakan di Kecamatan Gedangsari tahun 2015 dapat diketahui persentase jumlah suara yang berhasil dicapai masing-masing calon kepala daerah dengan total suara pemilih yang memilih sah mencapai 18.360. Suara ini merupakan sebagian $(56.16 \%)$ dari daftar pemilih tetap (DPT) sebanyak 30.014 dan apabila dilihat dari daftar pemilih sementara (DPS) yaitu mencapai $53.16 \%$ atau 31.547 serta apabila dilihat dari DP4 (daftar penduduk potensial pemilih pemilu) yaitu mencapai $50.87 \%$ atau DP4 tahun 2011 sebanyak 34.295 (Sumber: Dinas Kependudukan dan Catatan Sipil Kabupaten Kidul 2015).

Data tersebut di atas menunjukkan terjadinya perbedaan jumlah pemilih, berdasarkan data dari Dinas Kependudukan dan Catatan Sipil Kabupaten Gunung Kidul diketahui bahwa jumlah DP4 di kecamatan Gedangsari tahun 2015 sebanyak 34.295 orang sedangkan DPS yang ditetapkan oleh KPU hanya mencapai 31.547 orang atau menyusut sebanyak $4.3 \%$ dari DP4. Kemudian apabila dibandingkan dengan DPT menyusut sebanyak $9.4 \%$ menjadi 30.014 orang. Jarak desa Tegal Rejo ke Pemerintah Daerah Kabupaten Gunung Kidul sejauh $45 \mathrm{~km}$ sedangkan jarak ke Pemerintahan DIY sejauh $50 \mathrm{~km}$, dan terdapat dua dusun yang belum ada aliran listrik yaitu Dusun Gupit dan Dusun Ketelo (Sumber: Dinas Kependudukan dan Catatan Sipil Kabupaten Kidul).

Salah satu daerah terpencil yang tingkat partisipasinya sangat rendah di kecamatan Gedangsari adalah desa Tegalrejo. Desa ini terletak di daerah perbukitan yang menjadi salah satu daerah rawan bencana, terdiri dari 11 dusun di antaranya Gupit, Ketelo, Cremo, Tengklik, Candi, Prengguk, Tegalrejo, Tanjung, Trembono dan Hargosari. Desa Tegal Rejo memiliki $11 \mathrm{RW}$ dan $54 \mathrm{RT}$ dengan jumlah penduduk 8.197 berjenis kelamin laki-laki dan 4.135 perempuan serta terdiri dari 2.386 kepala keluarga. yang sebagian masyarakat berprofesi sebagai petani.

Berdasarkan hasil tulisan Muhammad Asfar dalam "Presiden Golput", Efriza (2012:537-544) setidaknya menyimpulkan ada empat faktor yang menjadi penyebab golput, yaitu:

\section{Faktor Psikologis}

Faktor ini berkaitan dengan ciri-ciri kepribadian seseorang dan orientasi kepribadian. Perilaku golput berkaitan dengan kepribadian seseorang melihat bahwa kepribadian yang tidak toleran, otoriter, tak acuh, perasaan tidak aman, perasaan khawatir, kurang mempunyai tanggung jawab secara pribadi, dan semacamnya.

2. Faktor Sistem Politik

Faktor ini berkaitan dengan sistem politik khususnya sistem pemilu secara langsung. Pemilih melakukan protes terhadap sistem politik dan sistem pemilu terutama kecewa dengan kebijakan dan implementasi dari pemerintah. Sistem politik yang dibangun rezim berkuasa saat ini dirasakan pemilih tidak mampu membangun demokrasi yang sehat. 


\section{Faktor Kepercayaan Politik}

Faktor ini sebagai bentuk perilaku golput sebagai ekspresi atas kepercayaan yang rendah terhadap sistem politik atau sebagai suatu ekspresi atas perasaan keterasingan (alienasi). Fenomena faktor kepercayaan politik ini biasanya muncul karena ketidakpercayaan terhadap saluran politik dalam bentuk partai dan akhirnya adanya keinginan warga negara untuk melakukan delegitimasi politik terhadap kekuasaan.

4. Faktor Latar belakang Status Sosial-Ekonomi

Faktor ini terbagi lagi ke dalam tiga indikator, yaitu tingkat pendidikan, tingkat pekerjaan, dan tingkat pendapatan. Raymond E. Wolfinger dan Steven J. Rossenstone menjelaskan bahwa:

a. Tingkat pendidikan tinggi menciptakan kemampuan lebih besar untuk mempelajari kehidupan politik tanpa rasa takut, sedangkan yang kurang berpendidikan berpengaruh untuk menghindari politik karena kekurangan mereka terhadap kepentingan dalam proses politik.

b. Tingkat pekerjaan tertentu lebih menghargai partisipasi warga. Para pemilih yang bekerja di lembaga berkaitan langsung dengan pemerintah cenderung lebih tinggi tingkat kehadirannya dalam pemilu dibandingkan para pemilih yang bekerja pada lembaga yang tidak mempunyai kaitan langsung dengan kebijakan pemerintah.

c. Tingkat pendapatan tinggi memudahkan orang menanggung beban finansial akibat keterlibatannya dalam proses pemilu. Menurut Raymond E. Wolfinger dan Steven J. Rossenstone, para pemilih yang tingkat pendapatannya rendah cenderung menunjukkan angka ketidakhadiran cukup tinggi dan sebaliknya.

\section{B. Analisa Data}

Data tentang sosialisasi KPU di pemilu kecamatan Gedangsari yang kurang berjalan, dikarenakan jumlah partisipasi pemilih yang rendah dan tingkat kesalahan dalam mencoblos yang cukup tinggi. Dalam hal ini KPU kurang efektif dalam melakukan sosialiasi pemilu di kecamatan Gedangsari terutama di desa Tegalrejo pada tahun 2015 .

Penyebab kurangnya pasrtisipasi pemilih di daerah terpencil dalam buku Efriza yang berjudul "polical exsplore: sebuah kajian ilmu politik". menurut Efriza (2012: 538-543) juga dikarenakan oleh berbagai faktor dari masyarakat sendiri, di antaranya adalah faktor teknis, faktor psikologis, faktor kepercayaan politik dan faktor latar belakang ekonomi. Faktor teknis disebabkan oleh kurangnya informasi masyarakat terhadap pemilu, tata cara ke TPS, aturan mencoblos, informasi calon, perubahan sistem, dan syarat-syarat untuk menjadi Daftar Pemilih Tetap (DPT). Faktor teknis juga bisa disebabkan oleh kesalahan administratif dari KPU seperti warga tidak terdata atau tidak mendapat undangan dari KPU. Faktor psikologis diantaranya karena lemahnya kesadaran masyarakat, tidak toleran, memiliki sifat acuh, mementingkan pekerjaan (prioritas kerja), sifat malas, dan jarak ke TPS yang cukup jauh.
Faktor lain adalah kepercayaan politik disebabkan oleh ketidakpuasan masyarakat kepada sistem politik, minimnya calon potensial dan berprestasi, jenuh terhadap pilihan dan tidak puas dengan janji-janji politik. Kemudian faktor latar belakang ekonomi juga menjadi penyebab kurangnya partisipasi pemilih di daerah terpencil, masyarakat dengan faktor kemiskinan ekonomi, pendidikan yang rendah dan kebutaan terhadap sisitem pemilihan umum dan politik.

Selain itu penyebab kurangnya angka partisipasi pemilih adalah sedikitnya pengetahuan dan informasi masyarakat tentang pemilu di daerah-daerah terpencil termasuk yang terjadi di desa Tegalrejo kecamatan Gedangsari. Sebagai salah satu bagian dari keberlanjutan demokrasi, tingkat partisipasi pemilih di daerah terpencil juga akan berdampak pada siapa yang akan memenangkan pemilu dan mengatur kehidupan banyak orang. Oleh karena itu sosialisasi KPU ke daerah-daerah terpencil harus diutamakan dan ditingkatkan efektifitas penyampaian sosialisasi untuk meningkatkan partisipasi pemilih daerah terpencil pada Pemilihan Umum tahun 2019.

Dari permasalahan yang ada, dapat dianalisis bahwa KPU membutuhkan sebuah media tambahan dalam kegiatan sosialisasi yang mampu menjelaskan kebutuhan masyarakat secara tepat, mudah dimengerti, dan dapat diingat oleh masyarakat daerah terpencil. Media tambahan tersebut dapat berupa media visualisasi dalam bentuk cetak yang dapat mendukung dan membantu KPU dalam sosialisasi ke masyarakat daerah terpencil sehingga masyarakat lebih mudah memahami setiap informasi dan pesan yang disampaikan oleh KPU.

\section{Identifikasi Problem Perancangan}

Perancangan Permasalahan pemilu di daerah terpencil banyak disebabkan oleh faktor teknis dan non teknis seperti kurangnya informasi mengenai tata cara mencoblos, pengenalan calon dan tidak mengetahui aturan-aturan yang ada ketika di TPS. Oleh karena itu dibutuhkan sebuah solusi untuk mengatasi masalah kurangnya informasi ini, penulis menemukan sebuah solusi yang dibutuhkan yaitu dengan membuat perancangan media pendukung yang dapat membantu dan menudahkan KPU dalam mensosialisasikan pemilu di daerah-daerah terpencil. Perancangan media pendukung ini bertujuan sebagai media pemberi informasi yang akurat dan lebih mudah dipahami dengan bantuan bentuk visual yang menarik sehingga setiap masyarakat dapat memahami informasi menjadi lebih mudah.

Penulis membuat perancangan bertema "Ngene Lho" sebagai media penyampaian informasi mengenai Pemilu 2019, tujuan dari perancangan dengan tema ini adalah agar masyarakat lebih mudah memahami informasi, dan mengerti semua yang disampaikan, sehingga meningkatkan kecerdasan masyarakat dan mengurangi masalah kekurangan informasi di kawasan daerah terpencil. 


\section{Media Utama}

Media utama merupakan media yang berperan sebagai media yang paling menonjol dan diutamakan dalam promosi produk/jasa itu sendiri. Pada media utama yang akan dipromosikan adalah video dokumenter Kampung Arab Al-Munawwar. Media utama inilah yang akan dipromosikan secara komersil kepada remaja sampai dewasa dan masyarakat umum yang dituju.

\section{E. Upaya Terdahulu}

Salah satu upaya KPU provinsi Yogyakarta dalam sosialisasi Pilpres 2019 kepada masyarakat dilakukan pada tanggal 11-25 November 2018 membuka booth pada pukul 17.00 WIB bertempat di acara Sekaten, Yogyakarta. Kegiatan sosialisasi ini berisi media-media yang dimiliki KPU seperti, leaflet, mug, t-shirt dan beberapa game untuk menarik minat kalangan muda untuk datang ke booth KPU.

Kegiatan ini dilakukan sebagai upaya KPU provinsi Yogyakarta dalam mengurangi angka golput pada pemilihan umum. Diharapkan dengan dilakukannya sosialisasi ini akan menyadarkan masyarakat ataupun kalangan pemuda untuk menggunakan hak pilihnya sebagaimana mestinya dan tidak menjadikan golput sebagai sebuah pilihan.

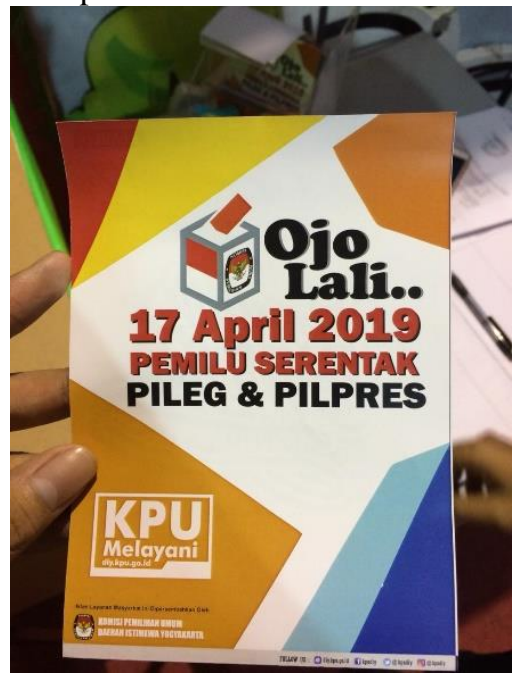

Gambar 1. Leaflet KPU Provinsi Yogyakarta

\section{F. Usulan Pemecahan Masalah}

Permasalahan berupa tingginya angka kesalahan masyarakat dalam mencoblos, terutama oleh masyarakat yang tinggal di daerah terpencil menjadi tantangan bagi KPU untuk mengurangi angka tersebut. Kesalahan dalam mencoblos yang menyebabkan angka golput juga tinggi disebabkan oleh kurangnya pengetahuan masyarakat terhadap aturan teknis dalam mencoblos, sosialisasi KPU masih belum memiliki hasil yang signifikan dalam upaya memberikan informasi pemilu kepada masyarakat di daerah terpencil.

Oleh karena itu, KPU membutuhkan sebuah perancangan media komunikasi visual berupa Infografik sebagai media pendukung yang efektif untuk meminimalisir tingkat kesalahan dalam mencoblos dan mengurangi angka golput di kawasan masyarakat daerah terpencil. Media yang digunakan berupa media cetak seperti Infografik, Poster dan Katalog. Dengan menggunakan konsep dan strategi kreatif yang jelas, akan mampu memberikan informasi yang lebih lengkap dan mudah dipahami oleh masyarakat di daerah terpencil.

\section{G. Konsep Kreatif}

Perancangan infografik sebagai media pendukung sosialisasi KPU ke daerah terpencil merupakan sebuah perancangan yang bersifat sosial, adapun isi pesan yang akan disampaikan kepada masyarakat daerah terpencil khususnya di Desa Tegalrejo Kecamatan Gedangsari Yogyakarta adalah berupa informasi yang dikemas dalam bentuk visual dan data aktual untuk memberikan pengetahuan tentang Pilpres 2019 mengenai informasi tata cara mencoblos di TPS, menjelaskan secara rinci alur dan proses yang benar ketika pemilih berada di TPS, kemudian menginformasikan aturan yang benar dan aturan yang salah ketika pemilih mencoblos surat suara, selanjutnya memberikan informasi mengenai syarat pemilih untuk menjadi DPT (Daftar Pemilih Tetap), kemudian pesan yang disampaikan adalah informasi mengenai profil dan data pribadi Pasangan Calon Presiden, baik berupa visi dan misi Paslon maupun data pribadi setiap Calon Presiden dan Calon Wakil Presiden. Penyampaian pesan dikemas dengan bantuan visual berupa ikon dari setiap objek informasi yang disampaikan, hal ini bertujuan untuk memudahkan khalayak sasaran dalam memahami dan mudah menerima setiap informasi yang diberikan.

Bentuk pesan yang digunakan dalam perancangan infografik sebagai media pendukung sosialisasi KPU ke daerah terpencil adalah kalimat pesan yang menggunakan bahasa daerah khalayak sasaran, yakni memakai bahasa jawa. Penggunaan bahasa jawa ini bertujuan sebagai strategi pendekatan kepada khalayak sasaran agar pesan yang ingin disampaikan lebih dikenal dan cepat diterima oleh masyarakat daerah terpencil karena bahasa Jawa merupakan bahasa keseharian masyarakat Desa Tegalrejo Kabupaten Gunung Kidul.

Bahasa merupakan kekuasaan (language is power) dan sangat berperan dalam mencapai tujuan nasional maupun internasional suatu bangsa. Bahasa membentuk suatu ikatan sosial melalui interaksi dan proses saling mempengaruhi penggunanya (Kurniawan, 2003).

\section{H. Tema Pesan}

Tema pesan dalam perancangan ini adalah sebuah anjuran yang menunjukan suatu hal itu dapat terlihat mudah. Dalam bahasa jawa yang merupakan bahasa sehari-hari khalayak sasaran, tema tersebut adalah "Ngene Lho" yang berarti "Begini Lho" merupakan sebuah kata yang memberi tahu informasi kepada sasaran yang dituju. Istilah Ngene Lho akan digunakan sebagai tema perancangan agar khalayak sasaran yang dituju merasakan sebuah pemberitahuan yang dapat menginformasikan pengetahuan yang dibutuhkan oleh masyarakat daerah terpencil bahwa aturan mencoblos, tata cara, dan profil Pasangan Calon Presiden itu "Ngene Lho". "Ngene Lho" dapat menambah wawasan 
masyarakat secara sederhana dan mampu memberikan ingatan yang kuat kepada pembacanya.

\section{Objek Visual}

Penggunaan objek visual yang digunakan dalam perancangan ini disesuaikan dengan pesan yang disampaikan yaitu menggunakan objek di kehidupan sehari-hari khalayak sasaran, objek visual yang dipakai adalah "Caping" atau Topi Petani. Caping merupakan alat penutup kepala atau sejenis topi yang berbentuk kerucut dan terbuat dari anyaman bambu yang biasa dipakai oleh petani di desa Tegalrejo. Penggunaan caping sebagai objek visual bertujuan sebagai media pendekatan kepada masyarakat daerah terpencil agar merasa pesan yang disampaikan ditujukan untuk dirinya sendiri.

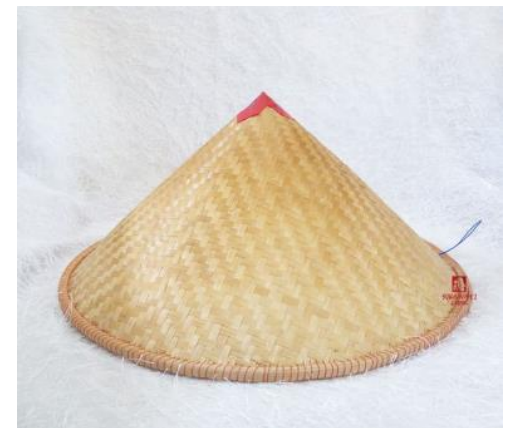

Gambar 2. Caping atau topi petani

Objek visual caping akan digambarkan dengan tokoh seorang petani laki-laki dan seorang perempuan yang menggunakan jilbab. Objek visual ini merepresentasikan pakaian sehari-hari masyarakat desa Tegalrejo, meskipun seorang petani juga harus menggunakan hak suaranya karena Pemilu bukan untuk kalangan atas saja, tetapi untuk semua masyarakat Indonesia tanpa memandang status sosial. Caping juga merupakan simbol kesederhanaan dari masyarakat daerah terpencil, harapan menggunakan caping ini adalah agar masyarakat tidak merasa asing dengan objek yang ditampilkan dan lebih mudah diterima karena sudah merupakan pakaian seharihari.

\section{J. Warna}

Konsep warna yang digunakan dalam perancangan ini adalah warna pantone dengan nuansa biru, abu-abu, tosca, orange, dan merah. Warna pantone seperti biru, tosca, orange dan merah merepresentasikan sebuah kebutuhan dan optimisme yang menyenangkan dan sesuai kondisi kebutuhan masyarakat daerah terpencil akan informasi pemilu yang aktual, warna pantone juga melambangkan kelembutan dan kenyamanan yang sesuai dengan cara penyampaian perancangan yang sederhana.

Sedangkan penggunaan warna abu-abu pada background perancangan mewakili kondisi kepribadian khalayak sasaran yang kebimbangan karena kurangnya informasi mengenai Pemilu di daerah terpencil. Warna ini dipadukan dengan warna pantone yang memiliki kesan pembaharuan atau solusi untuk memenuhi kebutuhan masyarakat di daerah terpencil.

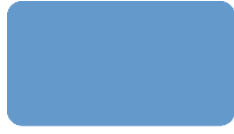

$\mathbf{R}=102 \mathbf{G}=152 \mathbf{B}=201$

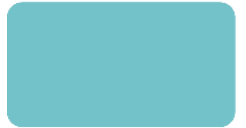

$\mathbf{R}=116 \mathbf{G}=193 \mathbf{B}=201$

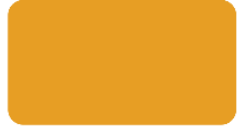

$\mathbf{R}=229 \mathbf{G}=157 \mathbf{B}=36$

$\mathbf{R}=215 \mathbf{G}=121 \mathbf{B}=123$

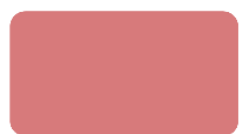

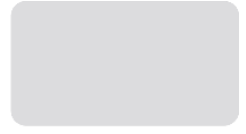

$\mathbf{R}=219 \mathbf{G}=219 \mathbf{B}=219$

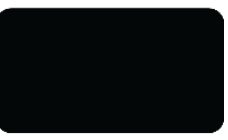

$\mathbf{R}=\mathbf{O} \mathbf{G}=\mathbf{O} \mathbf{B}=0$

\section{K. Gaya Tampilan Desain}

Gaya tampilan desain perancangan infografik ini menggunakan gaya flat design. Flat design adalah gaya desain dengan pendekatan minimalis yang menekankan kegunaan, dengan desain yang bersih tanpa ada bevel, bayangan, tekstur, berfokus pada tipografi, warna-warna cerah dan ilustrasi dua dimensi (Kelsey Campbell Dollaghan, 2013).

Gaya flat design ini dipakai dengan tujuan untuk menyederhanakan setiap objek visual, sehingga memberikan kesan sederhana dan menarik. Flat design memiliki tata layout yang terstruktur dengan tampilan visual yang logis. Flat design mampu meringkas informasi yang panjang dan rumit menjadi lebih sederhana dan mudah dimengerti. Kesederhanaan menjadi tujuan dari perancangan ini dengan maksud agar masyarakat daerah terpencil mampu menerima media, dan ketika melihat media pendukung ini menjadikan masyarakat cerdas dan cepat memahami setiap detail informasi.

\section{Pemilihan Media}

Perancangan infografik sebagai media pendukung sosialisasi KPU ke daerah terpencil juga dilakukan pemilihan media yang sesuai dengan tujuan dan strategi media. Pada prinsipnya jenis media dalam bentuk visual berupa media cetak, adapun pemilihan media yang akan digunakan dalam perancangan ini adalah sebagai berikut: 1. Infografik

Infografik merupakan media komunikasi visual yang berfungsi untuk menjelaskan informasi yang kompleks dengan efektif dan efisien (Newson \& Haynes, 2013). Infografik merupakan salah satu media informasi yang mampu memberikan informasi kepada khalayak sasaran secara interaktif dengan visual yang mudah dipahami, infografik pada umumnya biasanya berukuran dalam bentuk poster atau banner. Dengan menyajikan informasi secara detail, dengan tambahan visualisasi yang menarik dapat membawa daya tarik tersendiri. Pemilihan media poster dikarenakan media ini dapat memberikan informasi secara lebih detail, mudah dipahami dan dapat ditempatkan di berbagai lokasi yang sesuai dan mudah dilihat. Media Infografik dapat menyampaikan informasi yang rumit menjadi lebih ringkas, infografik juga merupakan media yang mudah diingat dengan penggabungan gambar dan teks yang menarik. Infografik yang digunakan dalam perancangan ini akan berbentuk $x$-banner sehingga mudah digunakan oleh KPU dalam bersosialisasi ke daerah terpencil. 


\section{Poster}

Poster merupakan salah satu media promosi yang cukup mampu memberikan ketertarikan kepada khalayak sasaran, poster pada umumnya biasanya berukuran antara 20x30 cm sampai 70x90 cm. Dengan menyajikan informasi secara detail, dengan selogan yang menarik ataupun dengan ilustrasi yang unik akan membawa daya tarik tersendiri. Pemilihan media poster dikarenakan media ini dapat memberikan informasi secara lebih dan dapat ditempatkan di berbagai lokasi yang sesuai dan mudah dilihat.

Poster memiliki kekuatan untuk dicerna oleh orang yang melihat karena poster lebih menonjolkan kekuatan pesan, visual dan warna. Hal tersebut sesuai dengan pandangan Nana Sudjana (2005:51) bahwa poster adalah media yang kuat warna, pesan, dan maksud untuk menangkap perhatian orang yang lewat, tetapi cukup lama menanamkan gagasan yang berarti dalam ingatannya. Poster dapat berupa gambar yang memiliki warna yang menarik sehingga dapat menangkap perhatian orang dengan menanamkan suatu makna tertentu yang ingin disampaikan pembuat poster, sesuai dengan tujuan dari makna poster tersebut.

\section{Katalog}

Katalog juga dipakai untuk kebutuhan penyampaian informasi. Hal ini dikarenakan di dalam sebuah katalog dapat mencantumkan pemberitahuan dan informasi pesan yang akan disampaikan dengan lebih lengkap dan lebih detail. Selain itu dalam katalog juga tercantum kata atau gambar yang mempunyai daya tarik untuk memberikan kemudahan dalam memahami informasi yang akan disampaikan.

Katalog bertujuan untuk memberikan informasi pasangan calon Presiden secara lebih detail, mulai dari profil setiap calon presiden, wakil presiden, dan juga visi misi yang diusung oleh setiap pasangan calon Presiden secara singkat dan mudah dipahami oleh masyarakat.

\section{Final Desain}
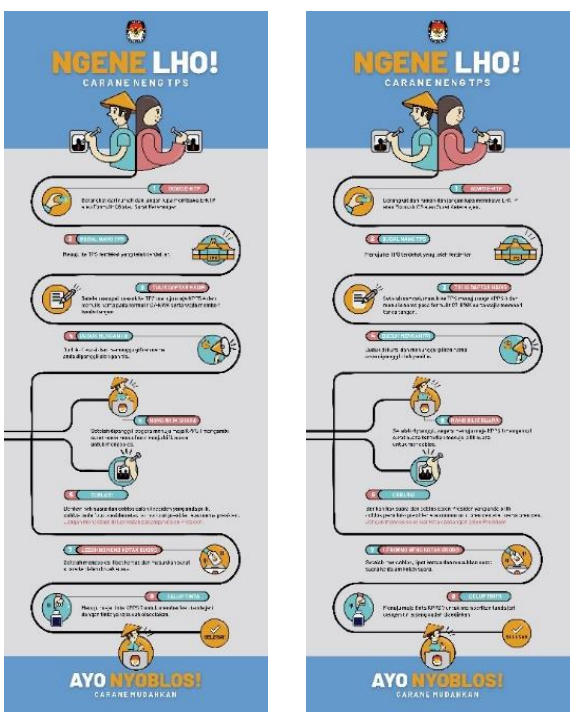

Gambar 3. Desain Infografik X-Banner

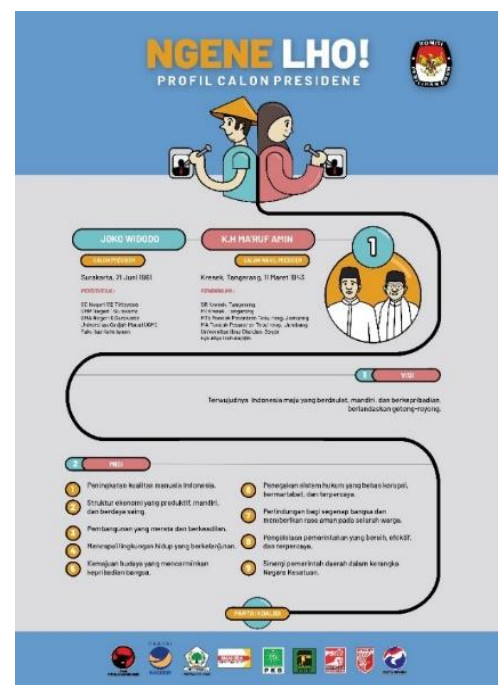

Gambar 4. Desain Poster Paslon 01

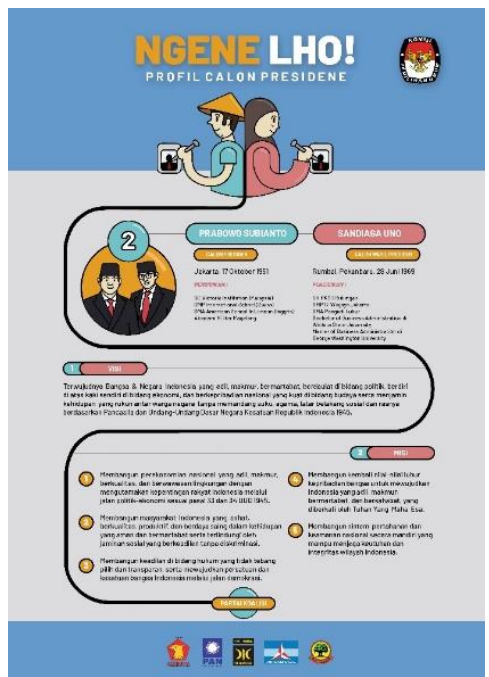

Gambar 5. Desain Poster Paslon 02
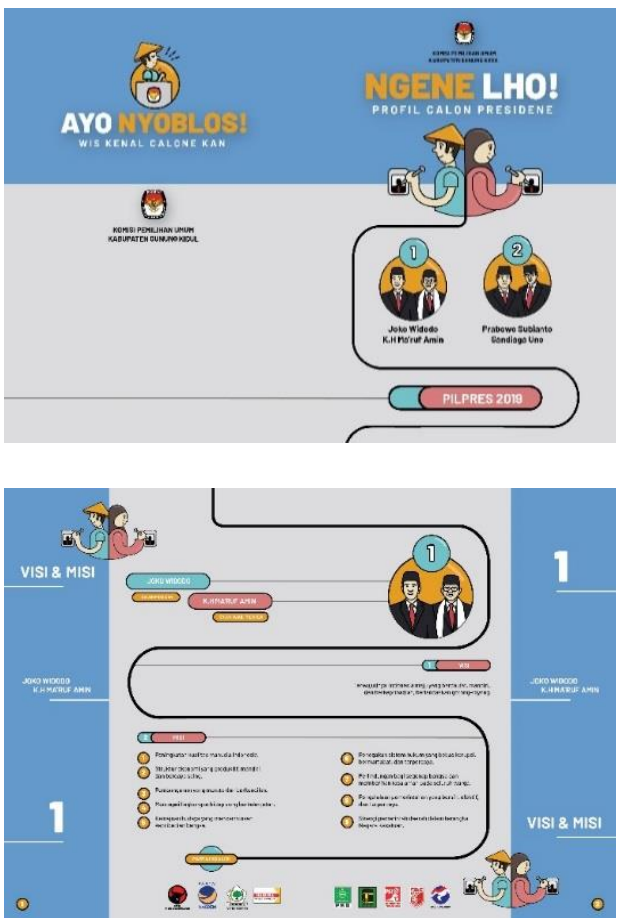

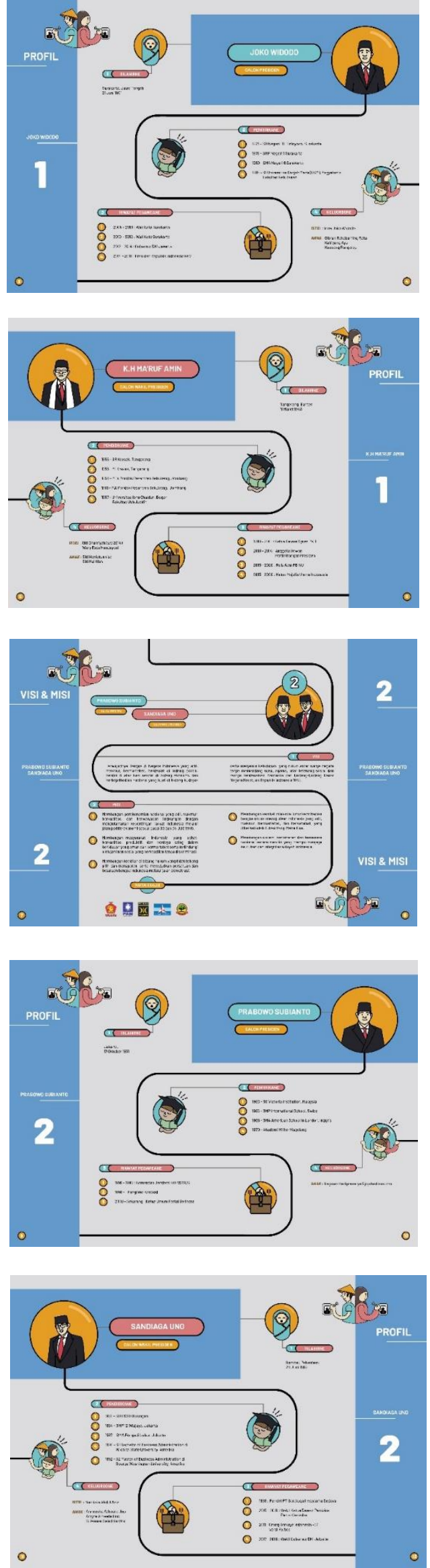

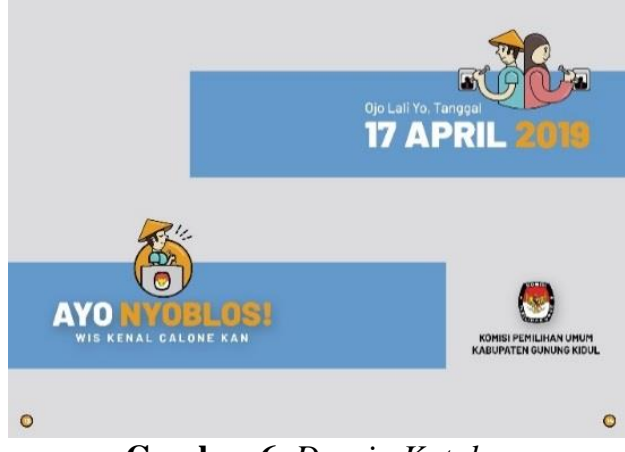

Gambar 6. Desain Katalog

N. Prototype dan Test

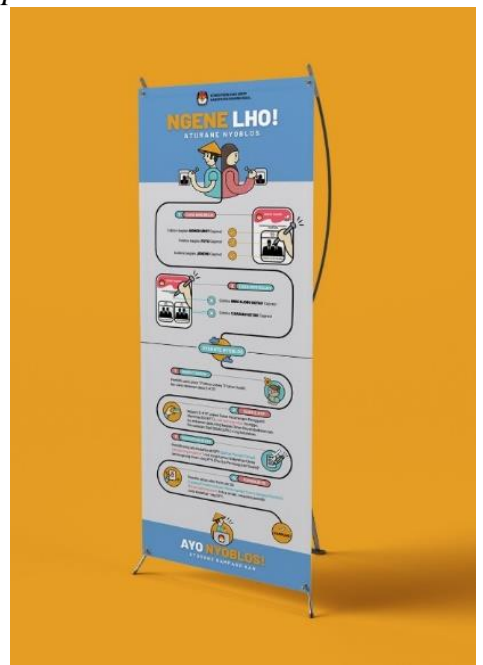

Gambar 7. Test Desain Infografik X-Banner

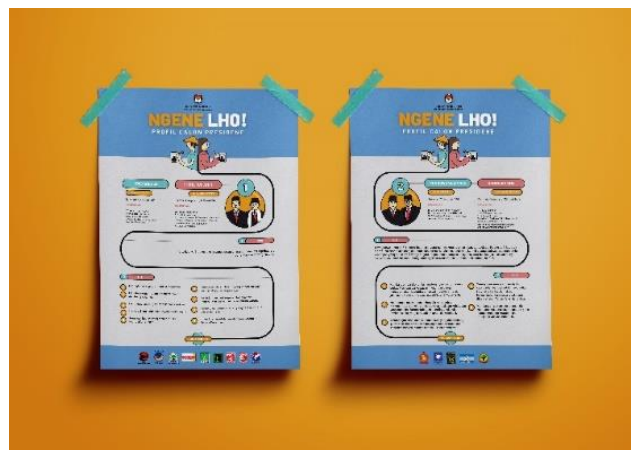

Gambar 8. Test Desain Infografik Poster

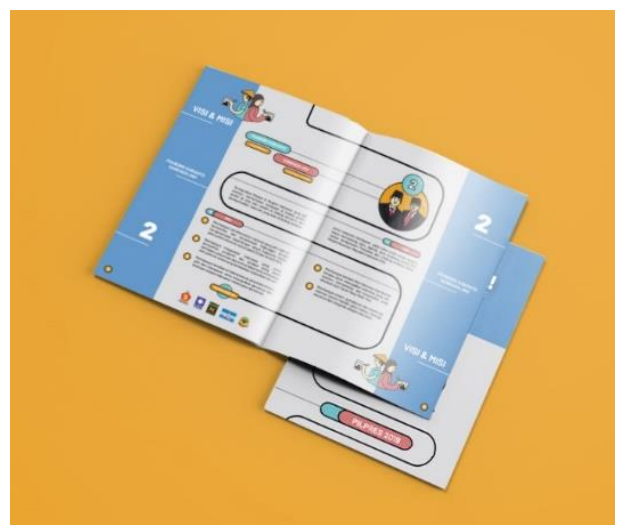

Gambar 9. Test Desain Infografik Katalog 


\section{Kesimpulan}

Permasalahan golput masih menjadi ancaman bagi Komisi Pemilihan Umum (KPU) dalam menghadapi Pilpres 2019, Hal ini sesuai dengan data hasil Pilpres 2009 dan 2014 yang mengalami penurunan partisipasi pemilih, dan mengakibatkan angka golput semakin tinggi. Banyak faktor yang menyebabkan terjadinya golput diantaranya berupa faktor psikologis, faktor kepercayaan, faktor sosial ekonomi, dan faktor teknis. Faktor teknis menjadi salah satu penyumbang angka golput tertinggi, disebabkan oleh kurangnya pengetahuan masyarakat, kesalahan mencoblos, tidak terdaftar di DPT, dan berbagai hal lain.

Salah satu penyebab faktor teknis ini adalah terjadi di kawasan daerah terpencil, yang kurang mendapatkan informasi Pemilu, baik informasi tata cara, aturan coblos, syarat-syarat yang harus dipenuhi, dan kurang mengenal calon yang akan dipilih. Kesalahan teknis ini diakibatkan oleh kurang efektifitasnya sosialisasi KPU ke daerahdaerah terpencil di Indonesia. Di Daerah Istimewa Yogyakarta terdapat daerah terpencil yang masih jarang dilakukan sosialisasi Pemilu oleh KPU, daerah tersebut adalah desa Tegalrejo kecamatan Gedangsari kabupaten Gunung Kidul, desa ini merupakan daerah perbukitan yang aksesnya sulit dijangkau dan juga termasuk daerah yang rawan terjadi bencana. Masyarakat desa Tegalrejo masih banyak yang melakukan kesalahan dalam mencoblos, tidak mengetahui aturan, dan kurang mengenal calon yang akan dipilih. Oleh karena itulah dibutuhkan sebuah perancangan yang dapat mengatasi masalah ini, maka dibuatlah "Perancangan Infografik Sebagai Media Pendukung Sosialisasi KPU ke Daerah Terpencil".

Perancangan infografik ini bertujuan untuk memberikan informasi Pemilu bagi masyarakat daerah terpencil, informasi yang disampaikan berupa permasalahan teknis meliputi proses mencoblos di TPS, aturan mencoblos surat suara, syarat menjadi DPT dan pengenalan Calon Presiden dan Calon Wakil Presiden. Perancangan ini menggunakan beberapa media komunikasi visual diantaranya adalah Infografik XBanner, Infografik Poster, dan Infografik Katalog. Media ini akan digunakan sebagai media pendukung pada sosialisasi KPU.

Harapan dari dibuatnya perancangan ini agar KPU di Kabupaten Gunung Kidul dapat meningkatkan efektivitas sosialisasi Pemilu ke daerah terpencil, media pendukung berupa infografik dapat menjadi salah satu solusi media yang mampu memberikan kemudahan dan pemahaman kepada masyarakat yang lebih baik dan untuk mengurangi angka golput di kawasan daerah terpencil, serta dapat mencerdaskan masyarakat terhadap informasi terkait Pemilu 2019.

\section{Daftar Pustaka}

Anggraini S, Lia., Nathalia, Kirana. 2014. Desain Komunikasi Visual; Dasar-Dasar Panduan Untuk Pemula. Nuansa Cendikia. Jakarta.
Ebdi Sanyoto, Sadjiman. 2006. Metode Perancangan Komunikasi Visual Periklanan. Dimensi Press, Yogyakarta.

Krum, R. 2013. Cool Infographics: Effective Communication with Data Visualizationand Design. John Wiley \& Sons.

Lankow, J., \& Ritchie, J. 2014. Infografis: Kedahsyatan Cara Bercerita Visual. Jakarta: Gramedia Pustaka Utama.

Rustan, Surianto. 2009. Layout Kasar dan Penerapannya. Jakarta: Gramedia Pustaka Utama.

Sihombing, Danton. 2001. Tipografi dalam Desain Grafis. Jakarta: Gramedia Pustaka Utama.

Tinarbuko Sumbo.2009. Semiotika Komunikasi Visual. Jalasutra.Yogyakarta.

Komisi Pemilihan Umum Daerah Istimewa Yogyakarta, www.diy.kpu.gi.id diakses pada tanggal 23 Desember 2018 Pukul 19.28 WIB. 